\title{
KOMITMEN PERNIKAHAN PADA PASANGAN SUAMI ISTRI BEKERJA
}

\author{
Latifatunnikmah*1, Sri Lestari $^{2}$ \\ ${ }^{1-2}$ Fakultas Psikologi Universitas Muhammadiyah Surakarta \\ J1. A. Yani Tromol Pos 1, Pabelan, Kartasura, Surakarta 57102 \\ *latifa.nikma@gmail.com ${ }^{1}$, sri.lestari@ums.ac.id ${ }^{2}$
}

\begin{abstract}
This research aim to describe how marital commitment in dual career family is formed. This research was conducted using phenomenological qualitative method. The data were collected by semi-structured interview with 6 dual career families who were less than 10 years of their marital age, having children less than 6 years old, and have been living in Surakarta. Thematic analysis was performed to analyze data. This research found that the commitment to couple is developed before marriage in several steps, begin with attracted to each other, then agree to increase the relationship to a marriage, and make an effort to cope with challenges. After married, marital commitment was given shape to role sharing, to meet the couples' need, to reduce the negative effects in facing some problem, and working as a teamwork.
\end{abstract}

Keywords: dual career family, marital commitment, phenomenological qualitative

\begin{abstract}
Abstrak
Penelitian ini bertujuan mendeskripsikan komitmen pernikahan pada pasangan suami istri bekerja. Metode penelitian yang digunakan adalah kualitatif fenomenologi. Data diperoleh melalui wawancara semi-terstruktur pada 6 pasang suami istri bekerja, lama waktu pernikahan kurang dari 10 tahun, mempunyai anak berusia kurang dari 6 tahun, dan tinggal di Karesidenan Surakarta. Analisis data menggunakan analisis tematik. Hasil penelitian menunjukkan bahwa komitmen pada pasangan mulai terbentuk sebelum menikah yang dibangun melalui tahap ketertarikan pada pasangan, membuat kesepakatan untuk menikah, dan menghadapi tantangan menuju pernikahan. Setelah menikah komitmen pasangan suami istri diwujudkan melalui pembagian peran, pengambilan keputusan, ijin suami bagi istri yang bekerja, evaluasi pada istri untuk bekerja atau berhenti kerja, mengatasi dampak dari sama-sama bekerja, dan menyelesaikan masalah bersama-sama. Bentuk perilaku untuk menjaga komitmen diwujudkan dengan sikap bertanggung jawab, setia pada pasangan, saling percaya, mau bekerja sama, saling memahami dan menghargai, serta taat terhadap ajaran agama memegang peran yang penting.
\end{abstract}

Kata kunci: komitmen pernikahan, kualitatif fenomenologi, pasangan suami istri 


\section{Pendahuluan}

Jumlah pasangan suami istri di Indonesia yang sama-sama bekerja senantiasa mengalami peningkatan. Hasil sensus penduduk pada tahun 2010 menyebutkan ada 27,92\% istri yang bekerja pada usia 25 - 44 tahun, baik yang tinggal di pedesaan maupun perkotaan (Badan Pusat Statistik, 2012). Penduduk perempuan yang bekerja di Surakarta mencapai 122.187 orang dengan prosentase $45,04 \%$ dari penduduk yang berkerja, menunjukkan bahwa semakin banyaknya perempuan yang aktif bekerja dalam keluarga (BPS Kota Surakarta, 2016). Duffy dan Atwater (2007) menjelaskan bahwa pekerjaan merupakan salah satu konflik pada pasangan suami istri yang dapat mengurangi keharmonisan. Demikian pula hasil-hasil penelitian di Indonesia menunjukkan bahwa konflik pada pasangan suami istri dapat timbul karena merasa kurang puas pada faktor keintiman khususnya keintiman secara fisik dengan pasangan karena waktunya habis digunakan untuk bekerja di luar rumah (Paputungan, Akhrani, \& Pratiwi, 2011). Penelitian Sari (2012) menunjukkan bahwa faktor yang menyebabkan konflik dalam dual career family di Indonesia adalah hadirnya anak, meningkatnya kebutuhan, banyaknya kegiatan baik yang bersifat sosial maupun terkait dengan pekerjaan dan kesulitan dalam membagi waktu untuk setiap kegiatan

Data dari Kementrian Agama RI (Takariawan, 2015a) menunjukkan bahwa perceraian setiap tahun mengalami peningkatan. Pada tahun 2009 sejumlah 216.268 kejadian, tahun 2010 ada 285.184 kejadian, tahun 2011 ada 258.119 kejadian, tahun 2012 ada 372.577 kejadian, tahun 2013 ada 324.527 kejadian meski pada tahun 2013 terjadi penurunan angka pernikahan namun perceraian tetap meningkat $14,6 \%$. Pada tahun 2014 ada 382.231 perceraian. Dari tahun 2010 sampai dengan 2014 peningkatan perceraian mencapai 52\% (Takariawan, 2015b).

Saputra (2016) menjelaskan dalam artikelnya bahwa pada tahun 2015, di Surakarta ada 796 kasus perceraian, pada bulan september 2016 jumlah perceraian sebanyak 754 kasus. Penyebab perceraian antara lain faktor tidak ada tanggung jawab antara suami dengan istri sebanyak 332 kasus, ketidakharmonisan sebanyak 126 kasus, pihak ketiga sebanyak 61 kasus, krisis akhlak sebanyak 49 kasus. Mooney, Oliver, dan Smith (dalam Jansen, 2013) tingkat perceraian menunjukkan sebuah ilustrasi objektif mengenai kehancuran dalam struktur keluarga dan komitmen.

Komitmen pernikahan adalah pengalaman pasangan suami istri yang bersamasama berupaya untuk mempertahankan pernikahan sebagai fungsi, bagian, dan interaksinya (Thompson \& Webb, 2004). Komitmen pada pasangan suami istri telah terbukti menjadi prediktor terkuat dalam menjaga stabilitas pernikahan (Clements \& Swenson, 2000), oleh sebab itu komitmen dijadikan sebagai cara untuk mempertahankan pernikahan, tetapi komitmen mengalami perubahan sejak awal pernikahan sampai terjalinnya hubungan dalam waktu yang lama (Burgoyne, Reibstein, Edmunds, \& Routh, 2010).

Mempertahankan pernikahan merupakan tanggung jawab dari semua pihak terutama pasangan suami istri. Banyak pengorbanan dilakukan oleh pasangan suami istri untuk mempertahankan stabilitas hubungannya. Monk (2010) menjelaskan bahwa pengorbanan juga memfasilitasi komitmen pasangan suami istri dalam menciptakan hubungan yang lebih baik.

Pasangan suami istri yang memilih untuk sama-sama bekerja menghadapi konsekuensi positif dan negatif dalam pernikahan. Konsekuensi positif menurut Kiong (dalam Desmayanti, 2009) antara lain adalah adanya kesiapan jika terjadi sesuatu pada 
pasangan hidup (meninggal/bercerai/ PHK, dll), meningkatkan pengertian istri terhadap suami karena mengetahui kondisi di luar rumah, dan sulitnya perjuangan hidup. Dampak negatif jika suami istri bekerja menurut Waite dan Gallagher (2000) adalah istri yang bekerja dan juga mengurus pekerjaan rumah tangga dapat meningkatkan ketegangan dan konflik dalam pernikahan. Waktu mereka banyak dihabiskan di luar rumah, sehingga urusan rumah tangga terabaikan terutama kepada anak, terlalu letih akibat terlalu lama bekerja, dan terjadi pendangkalan kasih sayang anak kepada ibu (Junaidi, 2009)

Tidak semua pasangan yang sama-sama bekerja memiliki komitmen pernikahan yang rendah dan berakhir pada perceraian, terbukti masih banyak pasangan suami istri bekerja yang mampu mempertahankan pernikahannya. Berikut ini kutipan wawancara dari pasangan yang sama-sama bekerja dan mampu menjaga komitmen.

Bisa mengayomi anak dan suami, bisa diajak kerja sama, ada suatu komitmen karena sama-sama bekerja, contoh komitmen karena sama-sama sibuk tidak boleh harus menuntut, misalnya saya harus...suami setiap pagi apa, istri setiap pagi apa. Nggak itu, harus ada kerja samanya mana yang repot mana yang tidak, saling mengisi satu dengan yang lain. (Wawancara dengan istri).

Sebagai suami menjadi leader tapi juga terbatas tidak boleh intervensi hak dan tugas istri. Misalnya harus masak ini ini tapi kan tidak, yang terbaik masak apa, (Wawancara dengan suami).

\section{Metode Penelitian}

Penelitian ini menggunakan metode kualitatif fenomenologi untuk memahami makna dari sebuah pengalaman yang sama dari beberapa individu yang kemudian dijelaskan secara universal (Creswell, 2013), yaitu dengan mengumpulkan data dari sejumlah informan kemudian membuat analisa dari berbagai pengalaman individu yang disajikan dalam sebuah data, diolah, dan dimaknai hingga didapatkan sebuah hasil yang dapat dijelaskan secara universal. Informan penelitian dipilih dengan teknik purposive sampling yaitu dengan menentukan karakteristik yang sesuai dengan gejala penelitian. Informan yang diwawancara diperoleh dengan turun ke lapangan secara langsung untuk menemukan informan yang sesuai. Informan yang menjadi sumber data adalah enam pasangan suami istri bekerja, yang telah menikah kurang dari 10 tahun, memiliki anak yang berusia kurang dari 6 tahun, dan berdomisili di Karesidenan Surakarta. Data demografi informan ditampilkan dalam Tabel 1.

Pengumpulan data dilakukan dengan wawancara semi terstruktur yang dirancang dengan pertanyaan-pertanyaan terbuka untuk memperoleh pandangan dan opini dari para partisipan. Wawancara dilakukan di rumah informan sesuai dengan waktu yang telah disepakati dengan informan. Panduan wawancara yang digunakan dicantumkan dalam Tabel 2. Interview dilakukan kepada pasangan suami istri secara terpisah, sebanyak dua kali pada waktu yang berbeda.

Teknik analisis data yang digunakan adalah analisis tematik. Langkah-langkah yang dilakukan dalam analisis data sebagai berikut: (1) mengorganisasikan data, (2) membuat verbatim dari hasil rekaman, (3) membaca dan memberi tanda/memo, (4) melakukan pengkodean untuk tema-tema yang muncul, (5) menemukan subtema, (6) melakukan kategorisasi, dan (7) interpretasi. Kredibilitas data yang diperoleh dicapai dengan member checking dan triangulasi data. Member checking dilakukan dengan cara 
menyampaikan hasil laporan akhir kepada informan untuk mengecek keakuratan informasi yang ditangkap peneliti dengan yang disampaikan oleh informan. Triangulasi data dioperasionalkan dengan memeriksa bukti-bukti yang berasal dari informan yang berbeda untuk memperoleh informasi yang sama, sehingga diperoleh data yang koheren.

Tabel 1.

Data demografi informan

\begin{tabular}{|c|c|c|c|c|c|c|c|}
\hline No & $\begin{array}{c}\text { Pasang } \\
\text { an }\end{array}$ & $\begin{array}{c}\text { Lama } \\
\text { menika } \\
\text { h }\end{array}$ & Status & $\begin{array}{l}\text { Pendidi } \\
\text { kan }\end{array}$ & Pekerjaan & $\begin{array}{l}\text { Usia } \\
\text { anak }\end{array}$ & $\begin{array}{c}\text { Jenis } \\
\text { kelamin } \\
\text { anak }\end{array}$ \\
\hline \multirow[t]{2}{*}{1.} & \multirow{2}{*}{$\begin{array}{c}\text { Pasang } \\
\text { an } 1\end{array}$} & \multirow{2}{*}{9 tahun } & Suami K & S-1 & $\begin{array}{c}\text { Pegawai } \\
\text { swasta }\end{array}$ & \multirow[t]{2}{*}{$\begin{array}{l}5 \text { th } 5 \\
\text { bln }\end{array}$} & \multirow[t]{2}{*}{$\underset{\mathrm{n}}{\text { Perempua }}$} \\
\hline & & & Istri L & SMA & $\begin{array}{c}\text { Buruh dan } \\
\text { usaha MLM }\end{array}$ & & \\
\hline \multirow[t]{2}{*}{2.} & \multirow{2}{*}{$\begin{array}{c}\text { Pasang } \\
\text { an } 2\end{array}$} & \multirow{2}{*}{3 tahun } & Suami A & SMA & $\begin{array}{c}\text { Pegawai } \\
\text { pemerintahan }\end{array}$ & \multirow[t]{2}{*}{3 th } & \multirow[t]{2}{*}{ Laki-laki } \\
\hline & & & Istri $\mathrm{N}$ & S-1 & $\begin{array}{c}\text { Karyawan } \\
\text { swasta }\end{array}$ & & \\
\hline \multirow[t]{3}{*}{3.} & \multirow{3}{*}{$\begin{array}{c}\text { Pasang } \\
\text { an } 3\end{array}$} & \multirow{3}{*}{5 tahun } & Suami & S-1 & Karyawan & \multirow[t]{3}{*}{3 th } & \multirow{3}{*}{$\begin{array}{c}\text { Perempua } \\
\mathrm{n}\end{array}$} \\
\hline & & & A.N & & bank & & \\
\hline & & & Istri $\mathrm{T}$ & S-1 & $\begin{array}{c}\text { Karyawan } \\
\text { bank }\end{array}$ & & \\
\hline \multirow[t]{2}{*}{4.} & \multirow{2}{*}{$\begin{array}{c}\text { Pasang } \\
\text { an } 4\end{array}$} & \multirow{2}{*}{4 tahun } & Suami S & S-1 & $\begin{array}{l}\text { Karyawan } \\
\text { bank }\end{array}$ & 3 th & Laki-laki \\
\hline & & & Istri D & D-3 & $\begin{array}{c}\text { Karyawan } \\
\text { bank }\end{array}$ & $\begin{array}{c}1 \text { th } 6 \\
\text { bln }\end{array}$ & $\begin{array}{c}\text { Perempua } \\
\mathrm{n}\end{array}$ \\
\hline \multirow[t]{2}{*}{5.} & \multirow{2}{*}{$\begin{array}{c}\text { Pasang } \\
\text { an } 5\end{array}$} & \multirow{2}{*}{4 tahun } & $\begin{array}{l}\text { Suami } \\
\text { A.S }\end{array}$ & S-1 & \multirow{2}{*}{$\begin{array}{l}\text { Pegawai } \\
\text { swasta } \\
\text { Dokter }\end{array}$} & $\begin{array}{c}3 \text { th } 7 \\
\text { bln }\end{array}$ & Laki-laki \\
\hline & & & Istri M.D & S-1 & & $\begin{array}{l}2 \text { th } 6 \\
\text { bln }\end{array}$ & $\begin{array}{c}\text { Perempua } \\
\mathrm{n}\end{array}$ \\
\hline \multirow[t]{2}{*}{6.} & \multirow{2}{*}{$\begin{array}{l}\text { Pasang } \\
\text { an } 6\end{array}$} & \multirow{2}{*}{2 tahun } & $\begin{array}{l}\text { Suami } \\
\text { A.D }\end{array}$ & S-1 & $\begin{array}{l}\text { Karyawan } \\
\text { bank }\end{array}$ & \multirow[t]{2}{*}{$11 \mathrm{bln}$} & \multirow[t]{2}{*}{$\begin{array}{c}\text { Perempua } \\
\mathrm{n}\end{array}$} \\
\hline & & & Istri D.W & S-1 & $\begin{array}{c}\text { Karyawan } \\
\text { bank }\end{array}$ & & \\
\hline
\end{tabular}

\section{Hasil dan Pembahasan}

Data penelitian yang diperoleh dipaparkan dengan membaginya dalam dua bagian yakni: (a) sebelum menikah dan, (b) setelah menikah.

a. Sebelum menikah

Sebelum menikah calon pasangan menunjukkan rasa saling tertarik, yang dilanjutkan dengan membuat kesepakatan bersama untuk menikah, dan bersama-sama menghadapi tantangan yang timbul untuk menuju jenjang pernikahan. Berikut dipaparkan data yang diperoleh lebih rinci. 
1) Ketertarikan pada pasangan

Ketertarikan perempuan kepada calon suaminya didasari oleh karakter, misalnya sabar, bisa menjadi pemimpin, ngemong, pekerja keras, setia, dan perhatian, seperti terungkap dalam kutipan wawncara berikut.

Orang nya baik, agamanya juga kuat (Pasangan 1,Istri L)

lebih ini lebih sabar, mungkin kalau cowok kan mungkin lebih pake logika ya jadi apa-apa nggak panik dulu gitu, bisa mengarahkan lah, ngasih tau bisa jadi imam lah apa juga dengerin baik eee gimana, ee..nggak pernah marah sama saya juga gitu. (Pasangan 3, Istri T)

Kelebihan nya ya (menghela nafas) apa ya ngemong ya mungkin (Pasangan 4, Istri D) kalau yang menarik dari suami orangnya seneng kerja keras sih (Pasangan 5, Istri M.D) Ya gak nakal, maksudnya ya ya playboy apa gimana. suamiku gak pernah marah, jarang marah sih. Soalnya sabar sih (Pasangan 6, Istri D.W)

Sementara laki-laki tertarik pada calon istrinya karena peduli, pandai, dan bisa menerima kondisi pasangan. Selain karakter juga karena adanya kecocokan, tertarik pada penampilan fisik, taat beragama, dan pekerjaannya.

satu agamane wis kuat, agamane kabeh sak keluargane kuat (Pasangan 3, Suami A.N)

Kelebihane ya itu pinter ngatur nyambut gawe pinter ngatur ekonomi (Pasangan2, Suami A)

kelebihannya itu istri ini...eee....dia mampu memahami kondisi saya mau menerima saya (Pasangan 3, Suami A.N).

ketertarikan kepada istri itu mandiri (Pasangan 4, Suami S).

yang penting kita ini cari yang cocok sama kita sama kita, kebetulan cocok yaudah (Pasangan 3, Suami A.N).

ya karna apa ya...banyak ya mbak ya, kalau cowok kan pastinya fisikly (Pasangan 4, Suami S).

ya dulu saya cari yang udah kerja, lha dia udah kerja ya udah saya tertarik di situ. (Pasangan 6, Suami A.D).

2) Membuat kesepakatan sebelum menikah

Kesepakatan sebelum menikah dibuat dengan calon pasangan dan keluarga yaitu mengenai pekerjaan dan pendidikan. Kesepakatan yang dibuat dengan calon pasangan mencakup pengelolaan keuangan, dan mengatasi perbedaan agama.

Kemarin nikah itu pun syaratnya setelah pendadaran. Jadi dua-duanya kelar, nikah jadi posisi wisuda bareng. (Pasangan 5, Istri M.D)

e..pada akhirkan ada e..aturan suami istri tidak boleh bekerja satu perusahaan, akhirnya kita berkomitmen untuk mencari kerja bareng-bareng nanti yang keterima istri atau saya itu kita cari pekerjaan (Pasangan 4, Suami S) 
selama satu tahun itu kan bertentangan dia ikut saya atau saya ikut dia gitu. Terus akhire wis apa akhire saya sing kalah, itu hehe. Cuma itu kendalanya sih mbak (Pasangan 2, Suami A)

3) Upaya menghadapi tantangan menuju pernikahan

Perjalanan menuju pernikahan tidak selalu lancar, pasangan mendapatkan tantangan-tantangan yang dapat menggoyahkan niat untuk berkomitmen dalam pernikahan. Tantangan tersebut berasal dari kondisi calon pasangan dan restu dari orang tua. Adapun tantangan dari orang tua mengenai kemapanan ekonomi dan pendidikan, serta status.

Menentangnya? karena satu status e janda, pasti itu pasti. emm padahal belum kenal. istilahnya belum pernah membayangkan kayak gitu lah, taunya ya ada dulu gosip miring banyak gosip miring yang didenger sama orang tua (Pasangan 1, Suami K)

Sebenarnya orang tua sih, karena waktu itu saya masih kuliah lho mbak. Semester akhir. Saya nggarap skripsi saya nikah. Nah, namanya orang tua orientasinya kan hidup mapan dulu. Cari pekerjaan (Pasangan 5, Suami A.S)

Permasalahan yang lain adalah hubungan jarak jauh. Seperti yang diungkap dalam wawancara dengan pasangan 2 oleh istri $\mathrm{N}$ )

Permasalahannya kan saya asli Surabaya, suami saya yang solo. Jadi memang perjalanan apa ketemunya itu jarang. Karena kan jarak (Pasangan 2, Istri N).

Tantangan lainnya adalah adanya perbedaan keyakinan agama yang dianut oleh pasangan. Ketika menghadapi kondisi tersebut, calon suami yang mengalah untuk mengikuti keyakinan agama calon istri, seperti diungkapkan dalam wawancara dengan Pasangan 2 oleh Suami A,

selama satu tahun itu kan bertentangan dia ikut saya atau saya ikut dia gitu. Terus akhire wis apa akhire saya sing kalah, itu hehe. Cuma itu kendalanya sih mbak (Pasangan 2, Suami A)

4) Pengambilan keputusan untuk menikah

Keputusan untuk menikah diambil setelah melalui tahap ketertarikan dan terpenuhinya kesepakatan yang dibuat seperti menyelesaikan pendidikan dan kemapanan pekerjaan serta menjalankan nilai-nilai agama, dan kematangan usia.

Yang memutuskan? Mungkin ya karena itu ya mbak faktor wis kita podo-podo senenge (Pasangan 2, Suami A)

Ya udah punya kerja sendiri-sendiri, jadi bisa buat nikah gitu (Pasangan 6, Istri D.W).

kedua yaa..ibadah, dalam arti ya masa ngga nikah, nikah itu ibadah, e...alasan lain ngga ada cuman itu tok (Pasangan 1, Suami K).

terus juga usia kita pernikahane ibarate terlalu tua dulu itu hehe...(Pasangan 2, Suami A). 
Desakan dari keluarga juga memberikan pengaruh pada informan untuk segera memutuskan menikah.

Cuma ya saya di.. itu lahir dari orang kampung mbak. dari cilacap, tradisinya masih. Jadi selagi masih muda ambil keputusan untuk nikah (Pasangan 5, Suami A.S)

b. Setelah Menikah

Setelah menikah komitmen pernikahan bersifat dinamis seiring dengan situasi dan kondisi yang dihadapi oleh masing-masing pasangan. Beragam upaya dilakukan pasangan untuk menjaga komitmen pernikahan yang telah dibentuk, yang dapat diuraikan sebagai berikut:

1) Pembagian peran

Pembagian peran yang dipilih adalah suami berperan sebagai pencari nafkah utama, sedangkan istri mencari nafkah tambahan. Istri yang bekerja tetap berkewajiban mengurus rumah dan mengasuh anak.

walaupun nambah penghasilan tapi tetep harus tahu posisi, posisi sebagai ibu sama suami, sama anak ada batasnya tahu (Pasangan 1, Suami K) yang jelas istri kerja itu nomer dua bukan tanggung jawab jadi cuman sekedar bantu aja (Pasangan 1, Suami K).

2) Pengambilan keputusan

Ada tiga cara dalam proses pengambilan keputusan, yakni: (1) suami sebagai pembuat keputusan dengan meminta pertimbangan istri, (2) keputusan dibuat bersamasama, dan (3) keputusan diambil oleh istri atau suami tergantung siapa yang dipandang lebih bertanggung jawab terhadap hal tersebut. Istri D.W (pasangan 6) misalnya memilih untuk berunding dengan suami dulu sebelum mengambil keputusan.

ehm..apa ya..sharing dulu sama suami baru ada keputusan yo wis berdasarkan sharing berdua terus memutuskan gitu (Pasangan 6, Istri D.W)

kalau memang diluar kemampuan saya ya dan istri menguasai seharusnya istri lebih monggolah, artinya dia punya punya apa ya pertimbangan untuk memilih tentunya dengan pertimbangan saya (Pasangan 4, Suami S)

3) Istri bekerja seijin suami

Apabila istri ingin bekerja, maka persyaratannya adalah harus ada ijin dari suami, dan istri diharapkan mampu membagi waktu untuk bekerja dan keluarga.

ijin suami ya kalau suami mengijinkan bekerja ya bekerja (Pasangan 1, Istri L) membagi waktu dengan porsinya dengan pas gitu loh mbak (Pasangan 3, Suami A.N)

4) Pertimbangan istri tetap bekerja atau berhenti bekerja

Pertimbangan istri bekerja adalah untuk membantu suami meningkatkan perekonomian keluarga, ekspresi diri, mengembangkan potensi, menjadi lebih mandiri, mengurangi keegoisan suami, dan memiliki kegiatan yang lebih bermanfaat. Istri yang 
memutuskan untuk berhenti bekerja memiliki pertimbangan agar pengawasan terhadap perkembangan anak lebih optimal, ekonomi keluarga sudah stabil, mengalami kelelahan, dan suami sudah tidak mengijinkan lagi untuk bekerja.

cuman untuk kedepannya eee saya sudah mapan kemudian misal suatu saat istri mau berhenti dan tidak mau mengerjakan ya ngga apa-apa sih (Pasangan 4, Suami S)

yang kedua kalau misalnya ada kendala sama anak saya yang memang butuh bimbingan dari ibuk e pengwasan ekstra kedua orang tua lah kudu ngalah kowe metu ngurusi anak (Pasangan 2, Istri N)

capek mbak, ikut orang itu capek, kan kita kan udah waktunya istirahat kan, disuruh apa..disuruh apa (Pasangan 1, Istri L)

5) Konsekuensi pasangan suami istri yang bekerja

Pasangan suami istri yang sama-sama bekerja berupaya menjaga komitmen pernikahan dengan menjadi keluarga yang mandiri secara ekonomi, saling memahami, dan mengatasi masalah-masalah yang muncul seperti berkurangnya waktu kebersamaan untuk pasangan maupun dengan anak, kesulitan mengerjakan tugas rumah, serta kelelahan yang dialami istri karena bekerja di luar sekaligus mengurus rumah tangga.

a) Perekonomian keluarga menjadi lebih stabil.

ya mungkin ekonominya bisa lebih kuat mbak. pemasukannya kan dua orang suami sama istri, beda sama satu orang, mungkin suami aja itu kan beda (Pasangan 6, Suami)

b) Kemampuan memahami pasangan

Pasangan suami istri yang sama-sama bekerja merasa mampu untuk memahami kondisi pasangan karena sama-sama tahu dan merasakan situasi dan kondisi bekerja di luar rumah. Sikap memahami tersebut diwujudkan dengan membuat suasana yang nyaman sepulang kerja, tidak banyak menuntut, dan memberikan toleransi pada pasangan

ya paling nggak kalau dia udah pulang kerja disana penat paling nggak ya dirumahlah bikin dia nyaman (Pasangan 5, Istri)

saat memang kerja lembur pulang malam pulang jam tujuhan itu kan suatu saat ketika porsi pekerjaan menumpuk di perbankan pulangnya juga lebih malam maka itu sudah tidak menjadi masalah sudah tahu dibidangnya seperti itu tapi kalau solusinya ya harusnya sama-sama tahu kelebihannya mba (Pasangan 4, Suami S)

c) Penghargaan dari lingkungan sosial

Istri yang bekerja mendapatkan penghargaan positif dari lingkungan sosial.

kelebihannya ya mungkin di lingkungan kantor, kalau di tanya temen istri kerja dimana, kan bisa menjadi nilai tambah bagi saya juga (Pasangan 6, Suami A.D) kelebihan saya kadang bisa sama temen-temen saya itu istri bekerja (Iter : ada kebanggaan (Pasangan 2, Suami A) 
d) Berkurangnya waktu untuk mengawasi anak

Kurangnya itu, kurang pengawasan otomatiskan kalau siang dititipkan lingkungannya gimana mungkin nggak sesuai dengan cara didik saya resikonya begitu jadi kadang ada kata-kata baru waaaa itu dapet dari mana (Pasangan 1, Suami K).

kadang lupa kalau anaknya harus nggarap pr kadang lupa og mbak. kecapekan kadang lupa kekurangannya itu. sama anak jadi kurang kurang fokus itu (Pasangan 1, Istri L).

e) Kesulitan menyelesaikan tugas rumah tangga dengan baik

Meskipun suami sudah membantu istri melakukan pekerjaan rumah tangga namun pekerjaan belum bisa diselesaikan dengan baik. Hal ini terjadi karena dalam pelaksanaan tugas rumah tangga tidak ada pembagian tugas yang pasti antara suami dan istri. Tugas rumah tangga dikerjakan oleh siapa yang longgar.

nek seumpama kabeh tak pasrahke bojoku yo mesakke wong bojoku yo nyambut gawe, nek aku ora ngewangi mesakke dee mulih kerjo kesel ijek ngumbahi ijek masak kan (Pasangan 2, Suami A).

seтиа, ya apapun semиa (iter: misalnya pak?) nggak ada ee.. kalau masalah anak istri kalau istri nggak sempat ya saya nyapu ngepel ya saya (Pasangan 4, Suami S).

f) Berkurangnya waktu kebersamaan.

Pasangan suami istri yang sama-sama bekerja memiliki kegiatan yang lebih padat. Istri melakukan pekerjaan di tempat kerja dan mengurus pekerjaan rumah tangga. Menjadikan suami atau istri sulit berkumpul dengan keluarga, anak, dan pasangan. Oleh sebab itu pasangan suami istri sama-sama bekerja menjadi lebih disiplin dalam memanfaatkan waktu.

e....kalau saya sih ngerasanya waktu ya, kurang untuk keluarga. apa lagi kalau waktu kerjanya itu kan samapai malem (Pasangan 4, Istri D)

kekurangannya yaitu waktu. Cuma sebentar ketemu adek aja yang kurang. kan keduanya pulang e malem-malem (Pasangan 6, Istri D.W)

g) Istri mengalami kelelahan

Mengerjakan dua pekerjaan sekaligus yaitu pekerjaan di tempat kerja dan tugas rumah tangga membuat istri mengalami kelelahan, seperti terungkap dalam kutipan wawancara berikut:

saya kadang kecapekan gitu kadang marah-marah sendiri hihihihi (Pasangan 1, Istri L)

6) Menyelesaikan masalah bersama

Pasangan suami istri yang bekerja, sebagaimana pasangan pada umumnya, juga berupaya menyelesaikan masalah dengan melakukan klarifikasi kepada pasangan apabila terjadi kesalah-pahaman. Pasangan juga berdiskusi untuk menyelesaikan masalah, dan bersedia untuk menerima saran dan penjelasan dari pasangan. 
sama-sama untuk berdiskusi dan memang yang bagusnya yang mana kan kita sendiri kan juga tetep bisa bisa tahu kan jadi nya ya kayak kayak masukan aja sih (Pasangan 4, Istri D)

ya kita kan kaya demokratif ya jadi ya diterima aja. apa maksudnya kalaupun kita keberatan ya kita dengerin alasannya apa kenapa keberatan kan gitu, nanti solusinya kayak gimana kan pasti ada (Pasangan 4, Istri D)

Penyelesaian masalah juga dilakukan dengan cara menenangkan diri terlebih dahulu lalu memberikan penjelasan pada pasangan, seperti yang terungkap pada kutipan wawancara berkut,

Penyelesaiannya memang butuh waktu nggak langasung selesai. tapi minimal satu hari tinggal tidur besok biasanya udah baik lagi. Ya memang didalamnya ada proses penjelasan (Pasangan 5, Suami A.S)

gak semuanya langsung diterima, jadi nanti ee butuh waktu itu lho nanti tak kasih pengertian seperti ini seperti ini, terus alasannya dia kenapa gak bisa kan tetep kita bicarakan gitu (Pasangan 2, Istri N)

Kalau aku tanggapi malah jadinya panjang. biasanya kalau udah lerem baru..ngomong sendiri (Pasangan 1, Suami K)

Upaya menyelesaikan permasa-lahan dengan mengalah dilakukan untuk mencegah pertengkaran yang berlarut. Upaya tersebut didorong oleh keinginan untuk tidak saling mendominasi. Suami bersedia menghargai posisi istri dari sudut pandang dan pendapat yang disampaikan oleh istri, sedangkan istri memiliki kemampuaun untuk menyampaikan pendapat dan berusaha menghargai suami sebagai pemimpin keluarga meskipun Ia juga bekerja.

maksudnya karena kita memang prinsipnya ee nggak udah kan salah satu nggak nggak mendominasi yadi ya nggak ya saling ngalah lah maksutnya saling ngalah itu ya (Pasangan 3, Istri T)

Yaitu tadi eee ya saling ini ya saling pengertian maksutnya saling ngalah tadi kalau kalau dua duanya egois kan jadinya berantem jadi kan saya sama suami juga ini aja sih saling mengerti gitu oh iya berarti ada benernya pasangan gini ada benernya saya bilang gini gitu (Pasangan 3, Istri T)

perbedaan pendapat kalau sama istri ya ngalah salah satu. kalau nggak gitu ya nggak pecah-pecah masalahnya. harus ada yang ngalah salah satu . (Pasangan 6, Suami A.D)

Penelitian ini bertujuan untuk mendeskripsikan perwujudan dinamika komitmen pernikahan pada pasangan suami istri yang sama-sama bekerja dalam kehidupan pernikahan. Hasil penelitian menunjukkan bahwa komitmen pasangan dimulai sejak belum menikah, yang diawali dengan ketertarikan pada calon pasangan, bersepakat untuk menikah, dan menghadapi tantangan bersama untuk menuju pernikahan.

Pada tahap sebelum menikah, terungkap bahwa semua pasangan mengalami ketertarikan pada pasangannya meski berbeda-beda sumber ketertarikannya. Sumber ketertarikan yang muncul pada seluruh pasangan adalah ketertarikan pada karakter pasangan. Karakter suami yang disukai misalnya kemampuan memahami kondisi, suami yang mampu memimpin, sabar, dan ngemong. Temuan ini selaras dengan 
pernyataan Sears, Freedman, dan Peplau (2009) bahwa dalam menjalin hubungan dengan orang lain, orang akan lebih tertarik dengan karakteristik yang menyenangkan seperti kompetensi dan kehangatan pribadi. Selain itu dalam menjalin hubungan orang cenderung menyukai orang lain yang mempunyai kesamaan sikap, nilai, minat, latar belakang, dan kepribadian.

Pernikahan yang disertai dengan adanya rasa saling tertarik pada pasangan dapat meningkatkan keinginan untuk tetap bersama dengan pasangannya. Salah satu pembentuk komitmen pernikahan adalah komitmen yang berasal dari diri sendiri yang didorong oleh ketertarikan pada pasangannya. Semakin tertarik seseorang dengan pasangannya maka semakin tinggi keinginannya untuk bersama (Johnson, Caughlin, \& Huston, 1999).

Adanya ketertarikan pada pasangan dan kesukaan terhadap karakter pasangan, mendorong pasangan bersepakat untuk melanjutkan hubungan ke jenjang pernikahan. Kesepakatan ini tidak hanya dibuat dengan pasangan, namun juga dengan orang tua dengan mempertimbangkan sisi positif dan negatif dari masing-masing pihak. Kesepakatan tersebut bertujuan untuk menyamakan pandangan mengenai kehidupan rumah tangga dan persyaratan untuk melanjutkan ke jenjang pernikahan. Hal ini didasari oleh kesadaran bahwa hubungan tidak hanya milik satu orang tetapi milik keduanya (Bakker, 2010).

Tantangan yang dihadapi oleh pasangan menuju pernikahan tidaklah mudah, terutama berasal dari orang tua, terkait dengan restu orang tua untuk menikah. Tantangan dari pasangan mencakup penyesuaian dengan kebiasaan dan prinsip pasangan, hubungan jarak jauh, dan perbedaan keyakinan. Pasangan suami istri menghadapi tantangan dengan bekerja sama untuk mencari alternatif solusi dari permasalahan yang sedang dihadapi. Seperti pada model pengelolaan konflik kolaboratif yaitu dengan adanya pemberian penjelasan dan diskusi dengan pasangan mengenai permasalahan yang dihadapi. Mencari penyelesaian yang mempertimbangkan kebaikan untuk keduanya, dan keluarga serta menghargai pendapat dan pilihan dari pasangan (Lestari, 2012).

Pasangan yang menjalin hubungan jarak jauh memilih untuk menambah frekuensi komunikasi dengan pasangan karena komunikasi yang lebih kerap dapat meningkatkan keakraban, meningkatkan rasa suka karena dinilai sebagai perilaku yang positif dan dilakukan berulang-ulang (Sears, Freedman, dan Peplau, 2009). Hal ini menunjukkan bahwa hanya pasangan yang bisa mengatasi tantangan sebelum menikah dan tetap bertahan dalam hubungan yang dapat melanjutkan ke tahap pernikahan. Upaya yang digunakan dalam mengatasi permasalahan juga memberikan pengaruh pada kepuasan yang berdampak pada komitmen pernikahan. Penyelesaian yang konstruktif bisa menguatkan komitmen yang dibangun.

Proses pembentukan komitmen sebelum menikah lebih jelasnya dapat dilihat pada Gambar 1 dan lebih detilnya mengenai perbedaan setiap informan dapat di lihat pada table. 2 


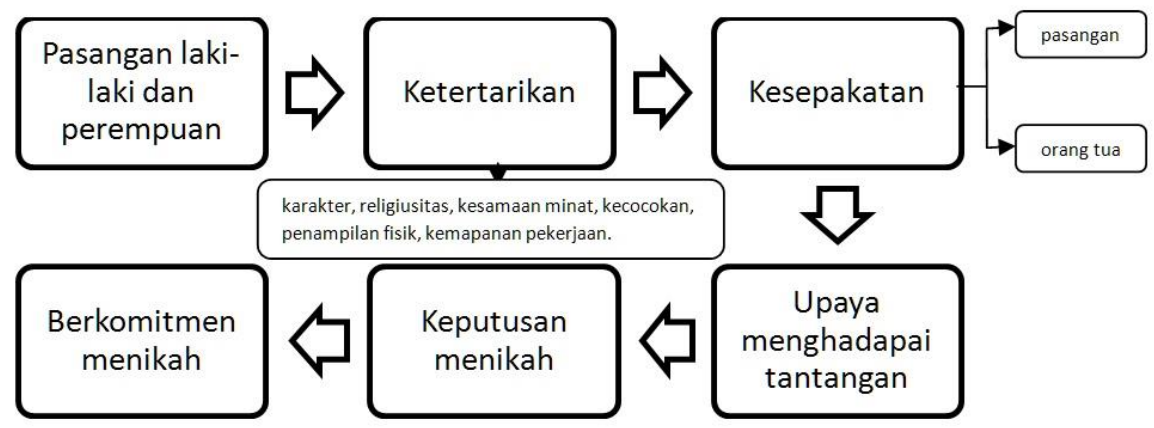

Gambar 1. Pembentukan komitmen sebelum menikah

Komitmen pernikahan pada pasangan mengalami perkembangan yang dinamis setelah memasuki gerbang pernikahan. Berbagai upaya dilakukan pasangan suami istri untuk menjaga komitmen pernikahan yang telah dibentuk, yakni:

Pertama, mendahulukan peran suami sebagai pencari nafkah utama, dan istri mencari nafkah tambahan. Pembagian peran tersebut diaplikasikan dengan istri bekerja namun tetap berkewajiban mengurus rumah dan mengasuh anak. Kondisi ini selaras dengan temuan Saraceno (2007) bahwa suami yang memiliki istri bekerja lebih peduli untuk melakukan pekerjaan rumah tangga dan merawat anak daripada yang hanya bekerja sendiri.

Ada tiga bentuk pengambilan keputusan pada pasangan suami istri yakni: (a) suami sebagai pembuat keputusan dengan tetap meminta pertimbangan istri, (b) keputusan dibuat bersama-sama, dan (c) keputusan diambil oleh istri atau suami tergantung pada siapa yang menguasai urusan tersebut. Ketiga bentuk pengambilan keputusan tersebut muncul karena ketika seorang istri juga bekerja, istri memiliki kemampuan dan diberi kekuasaan oleh suami untuk ikut berkontribusi dalam pengambilan keputusan. Istri bekerja juga menjadi lebih berani dalam mengungkapkan pendapat dan lebih dipertimbangkan oleh suami dalam pengambilan keputusan (Putri, 2013)

Kedua, pasangan suami istri yang sama-sama bekerja, membuat kesepakatan tertentu mengenai pekerjaan yang dilakukan. Kesepakatannya adalah istri bekerja harus ada ijin dari suami, dan mampu mengatur waktu. Kesepakatan yang dibuat bertujuan untuk menjaga keutuhan keluarga. Ijin dari suami merupakan salah satu nilai kepatuhan yang digunakan sebagai syarat untuk bekerja.

Ketiga, Istri berhenti bekerja dan memfokuskan diri pada perannya mengurus pekerjaan rumah tangga guna memenuhi kebutuhan keluarga. Istri berhenti bekerja karena kondisi ekonomi keluarga sudah stabil, dan pekerjaan suami sudah mapan. Hal ini terjadi karena tujuan awal dari istri bekerja adalah untuk membantu perekonomian keluarga (Junaidi, 2009) sehingga setelah terpenuhi istri bisa berhenti dan lebih fokus untuk mengurus anak. Selama bekerja istri kurang memahami perkembangan sosial dan pendidikan dari anak, atau gangguan pada perkembangan anak. Kondisi tersebut membuat istri merasa situasi rumah tangga lebih membutuhkan perannya sebagai istri dan ibu. 
Tabel 2.

Komitmen Pada Pasangan Sebelum Menikah

\begin{tabular}{|c|c|c|c|c|c|}
\hline Informan & Ketertarikan & $\begin{array}{c}\text { Kesepakat } \\
\text { an }\end{array}$ & $\begin{array}{c}\text { Tantangan } \\
\text { yang } \\
\text { dihadapi }\end{array}$ & $\begin{array}{c}\text { Cara } \\
\text { menghadapi } \\
\text { tantangan } \\
\end{array}$ & $\begin{array}{c}\text { Keputusan } \\
\text { menikah }\end{array}$ \\
\hline Pasangan 1 & $\begin{array}{l}\text { karakter, } \\
\text { religiusitas, } \\
\text { dan kesamaan } \\
\text { minat }\end{array}$ & $\begin{array}{l}\text { tidak } \\
\text { membuat } \\
\text { kesepakata } \\
\mathrm{n}\end{array}$ & $\begin{array}{l}\text { restu orang } \\
\text { tua }\end{array}$ & $\begin{array}{l}\text { meyakinkan dan } \\
\text { memberikan } \\
\text { penjelasan }\end{array}$ & $\begin{array}{l}\text { lama menjalin } \\
\text { hubungan: } 2 \text { tahun. } \\
\text { Alasan: ibadah dan } \\
\text { ketertarikan }\end{array}$ \\
\hline Pasangan 2 & $\begin{array}{l}\text { karakter dan } \\
\text { religiusitas }\end{array}$ & $\begin{array}{l}\text { menyamak } \\
\text { an } \\
\text { keyakinan } \\
\text { agama, dan } \\
\text { pekerjaan }\end{array}$ & $\begin{array}{l}\text { perbedaan } \\
\text { agama dan } \\
\text { hubungan } \\
\text { jarak jauh }\end{array}$ & $\begin{array}{l}\text { pengenalan tata } \\
\text { cara ritual secara } \\
\text { terus menerus, } \\
\text { menambah } \\
\text { frekuensi } \\
\text { komunikasi }\end{array}$ & $\begin{array}{l}\text { lama menjalin } \\
\text { hubungan: } 1 \text { tahun. } \\
\text { Alasan: awal } \\
\text { membangun } \\
\text { hubungan bertujuan } \\
\text { menikah,kesepakatan, } \\
\text { ketertarikan, dan usia } \\
\text { sudah matang. }\end{array}$ \\
\hline Pasangan 3 & $\begin{array}{l}\text { kecocokan, } \\
\text { dan karakter }\end{array}$ & $\begin{array}{l}\text { dengan } \\
\text { orang tua } \\
\text { mengenai } \\
\text { pekerjaan }\end{array}$ & $\begin{array}{l}\text { restu orang } \\
\text { tua }\end{array}$ & $\begin{array}{l}\text { meyakinkan orang } \\
\text { tua }\end{array}$ & $\begin{array}{l}\text { lama menjalin } \\
\text { hubungan: } 6 \text { bln. } \\
\text { Alasan: lama } \\
\text { mengenal pasangan } \\
\text { sebagai teman, } \\
\text { ketertarikan, dan } \\
\text { restu orang tua } \\
\text { (kesepakatan) }\end{array}$ \\
\hline Pasangan 4 & $\begin{array}{l}\text { penampilan } \\
\text { fisik, } \\
\text { kecocokan, } \\
\text { dan karakter }\end{array}$ & $\begin{array}{l}\text { dengan } \\
\text { pasangan } \\
\text { mengenai } \\
\text { berpindah } \\
\text { pekerjaan }\end{array}$ & $\begin{array}{l}\text { hubungan } \\
\text { jarak jauh. }\end{array}$ & $\begin{array}{l}\text { menambah } \\
\text { frekuensi } \\
\text { komunikasi }\end{array}$ & $\begin{array}{l}\text { lama menjalin } \\
\text { hubungan: } 4 \text { tahun } \\
\text { Alasan: ketertarikan } \\
\text { dan bertujuan } \\
\text { menikah dari awal } \\
\text { membangun } \\
\text { hubungan }\end{array}$ \\
\hline Pasangan 5 & karakter & $\begin{array}{l}\text { menyamak } \\
\text { an } \\
\text { perbedaan } \\
\text { pemikiran } \\
\text { tentang } \\
\text { pengelolaa } \\
\text { n } \\
\text { keuangan, } \\
\text { dengan } \\
\text { orang tua } \\
\text { yaitu } \\
\text { menyelesai } \\
\text { kan } \\
\text { pendidikan }\end{array}$ & $\begin{array}{l}\text { kesibukan } \\
\text { masing- } \\
\text { masing, dan } \\
\text { restu orang } \\
\text { tua. }\end{array}$ & $\begin{array}{l}\text { saling memahami, } \\
\text { menyakinkan } \\
\text { orang tua }\end{array}$ & $\begin{array}{l}\text { lama menjalin } \\
\text { hubungan: } 3 \text { tahun } \\
\text { Alasan: memenuhi } \\
\text { kesepakatan untuk } \\
\text { menyelesaikan } \\
\text { pendidikan, desakan } \\
\text { dari keluarga, waktu } \\
\text { yang lama menjalin } \\
\text { hubungan, dan } \\
\text { prinsip pasangan } \\
\text { menikah muda }\end{array}$ \\
\hline Pasangan 6 & $\begin{array}{l}\text { kemapanan } \\
\text { pekerjaan, dan } \\
\text { karakter }\end{array}$ & $\begin{array}{l}\text { dengan } \\
\text { pasangan } \\
\text { yaitu } \\
\text { mengenai } \\
\text { pekerjaan }\end{array}$ & $\begin{array}{l}\text { tidak } \\
\text { adamasalah }\end{array}$ & & $\begin{array}{l}\text { lama menjalin } \\
\text { hubungan: } 1 \text { tahun } \\
\text { Alasan: ketertarikan } \\
\text { dan kemapanan } \\
\text { pendidikan serta } \\
\text { pekerjaan }\end{array}$ \\
\hline
\end{tabular}

Keempat, pasangan suami istri bersama-sama menanggung konsekuensi yang timbul karena sama-sama bekerja, yakni: Pasangan yang sama-sama bekerja mampu mencapai kondisi ekonomi keluarga yang lebih baik, sehingga dapat meningkatkan 
kebahagiaan dan kemajuan bagi keluarga, yaitu pertama masalah dalam pengasuhan anak. Pasangan yang sama-sama bekerja kurang memiliki waktu untuk melakukan pengawasan terhadap kegiatan anak, sehingga muncul perilaku buruk pada anak seperti menggunakan kata-kata kotor, dan membantah orang tua. Pasangan juga kurang memiliki waktu untuk melakukan pendampingan belajar pada anak, seperti membantu anak mengerjakan PR, dan jarang hadir dalam pertemuan wali murid di sekolah anak. Upaya yang dilakukan untuk mengatasi masalah dalam pengasuhan tersebut, para suami ikut turun tangan dalam melakukan pengasuhan anak dengan membantu para istri sehingga muncul kerja sama dengan sistem kompromi antara suami dan istri.

Kedua, permsalahan pasangan suami istri dituntut untuk bisa fleksibel dalam mengerjakan tugas-tugas rumah tangga. Padatnya aktivitas istri karena bekerja, membuat tugas rumah tangga belum bisa terselesaikan dengan baik meskipun suami sudah membantu. Kondisi ini terjadi karena istri masih bertanggung jawab penuh untuk mengerjakan tugas domestik dan tidak ada pembagian tugas yang pasti dengan suami.

Ketiga berkaitan dengan intensitas waktu, pasangan suami istri bekerja memiliki aktivitas yang lebih padat. Pasangan suami istri bekerja menggunakan dua strategi agar bisa bersama dengan pasangan, yaitu secara fleksibel memanfaatkan waktu secara maksimal dan sengaja meluangkan waktu untuk bersama dengan pasangan. Keempat, Kemampuan memahami pasangan. Pemahaman terhadap pasangan diwujudkan dengan membuat suasana yang nyaman sepulang kerja, tidak banyak menuntut, dan memberikan toleransi. Adanya pengertian dan penerimaan terhadap pasangan dapat meningkatkan kepuasan pada pasangan (Stinnet, Walters, \& Kaaye, 1984), dan kepuasan pernikahan tersebut membuat komitmen pernikahan juga semakin kuat. Hal ini berkaitan dengan Penghargaan diri, suami yang memiliki istri bekerja mendapatkan penghargaan yang positif dari lingkungan sosial dan merasa bangga dengan memiliki istri yang bekerja. Selain itu juga kaitan dengan kelelahan karena istri mengerjakan dua pekerjaan yaitu pekerjaan di luar rumah dan tugas rumah tangga. Menurut (Neault \& Pickerell, 2005) kelelahan dapat menimbulkan kesulitan menemukan kesimbangan dalam melakukan kegiatan dalam kehidupannya, menjadi mudah stress, dan sedikit energi untuk menghabiskan akhir pekan.

Kelima, penyelesaian masalah oleh pasangan suami istri yang sama-sama bekerja. Kesalahpahaman pada pasangan suami istri dapat terjadi karena cara berkomunikasi yang kurang tepat dengan menghindarkan kesalahpahaman, sebaiknya pasangan suami istri menggunakan gaya komunikasi positif yang menekankan pada sikap asertif dan menggunakan pernyataan (Lestari, 2012), oleh karena itu pasangan suami istri perlu memiliki keterampilan dalam berkomunikasi untuk menghindari timbulnya kesalahpahaman.

Kesalahpahaman diatasi dengan memberikan penjelasan kepada pasangan, berdiskusi untuk menyelesaikan masalah, dan ada kesediaan untuk menerima saran dan penjelasan dari pasangan. Stanley mengukapkan bahwa komitmen berhubungan dengan perilaku yang lebih konstruktif saat ada permasalahan dalam hubungan yang dijalani (disitasi Lambert \& Dollahite, 2008)

Cara lain yang dilakukan pasangan adalah mengalah untuk menghindari pertengkaran berlanjut. Cara tersebut dilakukan dengan pergi meninggalkan area pertengkaran atau mendiamkan pasangan untuk meredakan kemarahan, setelah tenang baru berbicara dengan pasangan. Penyelesaian masalah membutuhkan kemampuan untuk melakukan evaluasi diri dan menahan diri untuk tidak menggunakan kata-kata 
atau perilaku bermusuhan (Baron \& Byrne, 2005). Mengalah dan menenangkan diri terlebih dahulu, merupakan cara untuk menghindari perilaku bermusuhan.

Penyelesaian konflik yang konstruktif menunjukkan adanya konsistensi pada komitmen pernikahan yang dimiliki oleh pasangan untuk tidak menyerah pada permasalahan dan menghadapinya, untuk tetap mempertahankan pernikahannya (Johnson, Caughlin, \& Huston, 1999). Berdasarkan hasil dalam penelitian ini, pasangan suami istri berupaya untuk lebih memahami kondisi pasangannya, berpikiran lebih terbuka, tidak memaksakan kehendak, dan secara bersama-sama melakukan evaluasi diri untuk mencari jalan tengah yang tidak merugikan salah satu pihak dalam setiap permasalahan yang dihadapi.

Hasil penelitian menunjukkan dalam membangun keluarga perlu dilandasi dengan keyakinan agama yang kuat untuk menjadikan pernikahan yang bahagia. Sebagai keluarga, nilai-nilai keagamaan perlu diciptakan untuk kebaikan berumah tangga (Paputungan, Akhrani, \& Pratiwi, 2011). Nilai-nilai yang diyakini oleh pasangan kemudian dipraktikkan dalam kehidupan pernikahan karena pasangan suami istri memiliki kewajiban moral untuk melakukannya guna menjaga keberlangsungan pernikahannya (Johnson, dkk., 1999).

\section{Simpulan}

Komitmen pernikahan pada pasangan suami istri bekerja dibangun sejak sebelum menikah melalui ketertarikan pada pasangan, membentuk komitmen, dan berupaya menghadapi tantangan. Komitmen pada pasangan setelah menikah, dijaga melalui pembagian peran yang mempertimbangkan kebaikan kedua pihak, kesepakatan untuk meminimalkan dampak negatif, menjaga motivasi istri yang tetap bekerja, dan meningkatkan dampak positif dengan bekerjasama untuk menjaga komitmen yang telah terbentuk. Penguatan komitmen berdampak pada semakin berkurangnya dampak negatif pada pasangan suami istri bekerja.

\section{Daftar Pustaka}

Badan Pusat Statistik. (2012, April 23).www.bps.go.id. Retrieved 03 April, 2017, from Presentase rumah tangga menurut provinsi, jenis kelamin, KRT yang bekerja \& daerah tempat tinggal, 2009-2010: http://www.bps.go.id/tab_sub/view.php? tabel=I\&id_subjek=4o\&notab, 23 April 2012.

Bakker, A. (2010). Commitment, rituals, and initiator tendency in married couples. Utah: Utah State University.

Baron, R.A., \& Byrne,D. (2005). Psikologi sosial Jilid 2. Jakarta: Erlangga.

BPS Kota Surakarta. 2016. Kota Surakarta dalam angka. Surakarta: BPS Kota Surakarta

Burgoyne, C. B., Reibstein, J., Edmunds, A. M., \& Routh, D. A. (2010). Marital commitment, money and marriage preparation: What changes after the wedding? Journal of Community \& Applied Social Psychology, 20 (5), 390-403. 
Clements, R., \& Swensen, C. H. (2000). Commitment to one's spouse as a predictor of marital quality among older couples. Current Psychology, 19 (2),110-119.

Desmayanti, S. (2009). Hubungan antara resolusi konflik dan kepuasan pernikahan pada pasangan suami istri bekerja pada masa awal pernikahan. Skipsi. Fakultas Psikologi Universitas Indonesia, Jakarta.

Duffy, K. G., \& Atwater, E. (2007). Psychology for living: Adjusment, growth, and behavior today (9th ed). New Jersey: Prentice Hall.

Jansen, M.C. (2013). Meaningfulness as a predictor of intergenerational commitment. Tesis. Faculty of Education University of Pretoria, Pretoria.

Johnson, M. P., Caughlin, J. P., \& Huston, T. L. (1999). The tripartite nature of marital commitment: Personal, moral, and structural reasons to stay married. Journal of Marriage and The Family, 61(1), 180-177.

Junaidi. (2009). Upaya mewujudkan keluarga sakinah dalam keluarga karir (studi pada dosen wanita fakultas humaniora dan budaya universitas islam negeri maulana malik ibrahim malang). Tesis. Fakultas Humaniora dan Budaya Universitas Islam Negeri Maulana Malik Ibrahim, Malang.

Lambert, N. M., \& Dollahite, D. C. (2008). The threefold cord: Marital commitment in religious couple. Journal of Family Issues, 29(5), 592-614.

Lestari, S. (2012). Psikologi keluarga: Penanaman nilai dan penanganan konflik dalam keluarga. Jakarta: Kencana.

Monk, J. K. (2010). Commitment and sacrifice in emerging adult cyclical and noncyclical romantic relationships. Thesis. Kansas State University, Manhattan

Neault, R. A., \& Pickerell, D. A. (2005). Dual-career couples: The juggling act. Canadian Journal of Counselling, 39(3), 187-198.

Paputungan, F., Akhrani, A. L., \& Pratiwi, A. (2011, ). www.academia.edu. Retrieved April 6, 2017, from Kepuasan pernikahan suami yang memiliki istri berkarir: https://goo.gl/W24kdP, 2011.

Putri, D.P.K. (2013). Penerapan nilai rukun dalam penyesuaian pernikahan pada pasangan suami istri Jawa. Skrips. Fakultas Psikologi Universitas Muhammadyah Surakarta, Surakarta.

Saputra, A. (2016, Oktober 03). www.republika.co.id. Retrieved November 1, 2016, from Ini penyebab banyaknya kasus perceraian di surakarta: https://goo.gl/ywjXqu, 03 Oktober 2016.

Saraceno, C. (2007). Introduction to the special issue: Dual-career couples. Zeitschrift für Familienforschung, 19 (3), 255-262.

Sari, P. I. (2012). ejournal.umpwr.ac.id. Retrieved April 6, 2017, from Konflik peran pekerjaan dan keluarga pada pasangan berkarir ganda: http://download.portalgaruda.org/article.php?article=97997\&val=617, 2012.

Sears, D. O., Freedman, J. L., \& Peplau, L. A. (2009). Psikologi sosial Jilid 1. Jakarta: Erlangga. 
Takariawan, C. (2015a, Juni 17). www.kompasiana.com. Retrieved 11 1, 2016, from 40 Perceraian Setiap Jam!: http://www.kompasiana.com/pakcah/di-indonesia-40perceraian-setiap-jam_54f357c07455137a2b6c7115, 17 juni 2015.

Takariawan, C. (2015b, Desember 31). www.kompasiana.com. Retrieved November 1, 2016, from Catatan akhir 2015 perceraian masih terus meningkat: https://goo.gl/QesKsu, 31 desember 2015.

Thompson-Hayes, M., \& Webb, L. M. (2004). Commitment under construction: a dyadic and communicative model of marital commitment. The Journal of Family Communication , 4 (3-4), 249-260.

Waite, L. J., \& Gallagher, M. (2000). The case for marriage: Why married people are happier, healthier, and better off financially. New York: Broadway. 